\title{
ANALISIS KELAYAKAN USAHATANI KARET RAKYAT DI KECAMATAN LANGSA LAMA KOTA LANGSA
}

\section{(Feasibility Analysis of Rubber Farming System In Langsa Lama Sub-district Langsa City)}

\author{
Daris Hudaya $^{1}$, Makmur ${ }^{1}$, Mustafa $^{1^{*}}$ \\ ${ }^{1}$ Program Studi Agribisnis, Fakultas Pertanian, Universitas Syiah Kuala
}

\begin{abstract}
Abstrak.tingkat kesejahteraan petani sering dikaitkan dengan keadaan usahatani yang dicerminkan oleh tingkat pendapatan petani. Penerimaan yang berkurang akan diikuti dengan semakin rendahnya pendapatan yang diterima petani., penelitian ini bertujuan untuk mengetahui untuk mengetahui kelayakan usahatani karet rakyat di Kecamatan Langsa Lama Kota Langsa ditinjau dari aspek finansial dan aspek teknis.. Penarikan Pengambilan sampel dari masingmasing desa dilakukan dengan menggunakan metode acak sederhana (simple-random sampling). Dari 316 total populasi di ambil $10 \%$ maka sampel sebesar 32 orang. Teknik analisis yang digunakan pada penelitian ini adalah analisis kelayakan finansial.Hasil penelitian menunjukkan bahwa usahatani karet rakyat di kecamatan Langsa Lama Kota Langsa layak untuk diusahakan ditinjau dari aspek finansial dan aspek teknis.
\end{abstract}

Kata Kunci :Usahatani, aspek finansial, aspek teknis.

Abstract. farmers 'welfare level is often associated with farming conditions as reflected by farmers' income levels. Reduced revenue will be followed by the lower income received by farmers, this study aims to determine to determine the feasibility of rubber farming in Langsa Lama District Langsa City viewed from the financial aspect and technical aspects .. Withdrawal Sampling of each village is done with using simple random sampling method. Of the total population 316 taken $10 \%$ then the sample of 32 people. The analysis technique used in this research is financial feasibility analysis. The results showed that rubber farming in Langsa Lama district Langsa City is feasible to be sought in terms of financial and technical aspects.

Keywords :Farming, financial aspects, technical aspects.

\section{PENDAHULUAN}

Tanaman karet merupakan salah satu komoditi perkebunan yang menduduki posisi cukup penting sebagai sumber devisa non-migas bagi Indonesia, sehingga memiliki prospek produksi yang baik. Oleh sebab itu upaya peningkatan produktivitas usahatani karet terus dilakukan terutama dalam bidang teknologi budidaya. Perkebunan karet Indonesia dinilai strategis karena pada tahun 2005 mempunyai areal terluas di dunia yaitu mencapai 3.262 juta ha, volume ekspor karet Indonesia pada saat itu sebesar 1.874 juta ton merupakan salah satu sumber devisa kedua setelah kelapa sawit dengan nilai USD $\$ 2,18$ juta, dan merupakan sumber pendapatan bagi lebih dari 15 juta penduduk Indonesia (Dirjen Bina Produksi Perkebunan, 2010).

Sebagai salah satu komoditas perkebunan dengan nilai ekonomis tinggi, oleh karena itu, tidak salah jika banyak yang beranggapan bahwa tanaman karet adalah salah satu kekayaan Indonesia. Karet yang diperoleh dari proses penggumpalan getah tanaman karet (lateks) dapat diolah lebih lanjut untuk menghasilkan lembaran karet (sheet), bongkahan

*Corresponding author:musthafa_usman@unsyiah.ac.id 333 
(kotak), atau karet remah (crumb rubber) yang merupakan bahan baku industri karet (Suwarto, 2010).

Tabel 1. Luas Areal dan Produksi Karet di Kota Langsa Tahun 2012-2016

\begin{tabular}{llll}
\hline No. & Tahun & $\begin{array}{l}\text { Luas Areal } \\
\text { (Hektar) }\end{array}$ & $\begin{array}{l}\text { Produksi } \\
\text { (Ton) }\end{array}$ \\
\hline 1. & 2012 & 1.848 & 1.302 \\
2. & 2013 & 1.779 & 1.613 \\
3. & 2014 & 555 & 368 \\
4. & 2015 & 555 & 367 \\
5. & 2016 & 555 & 370 \\
\hline
\end{tabular}

Sumber :Badan Pusat Statistik (2017)

Dari tabel di atas, dapat dijelaskan bahwa pada tahun 2012 luas areal tanaman karet yaitu 1.848 Ha dengan produksi mencapai 1.302 ton, kemudian pada tahun 2013 luas areal yaitu mengalami penurunan menjadi 1.779 Ha akan tetapi terjadi peningkatan produksi mencapai 1.613 ton. Sedangkan pada tahun 2014, 2015 dan 2016 luas areal perkebunan karet mengalami penurunan signifikan dan statis menjadi 555 Ha dengan kapasitas produksi pada tahun 2014 yaitu 368 ton, tahun 2015 sebesar 367 ton dan pada tahun 2016 yaitu 370 ton.

Dari data di atas dapat dijelaskan bahwa sejak pertengahan tahun 2014 terjadi perluasan dalam perencanaan kota yang sebagian mencaplok lahan karet milik masyarakat untuk sentralisasi pusat pasar dan pemukiman. Oleh karena itu sejak tahun 2014 terjadi penurunan produksi karet di Kecamatan Langsa Lama Kota Langsa dikarenakan berkurangnya lahan karet milik masyarakat dari sekitar $1700 \mathrm{Ha}$ menjadi hanya $500 \mathrm{Ha}$.

\section{Perumusan Masalah}

Dari latar belakang yang telah diuraikan di atas, adapun rumusan masalah dalam penelitian ini adalah bagaimana kelayakan usahatani karet rakyat di Kecamatan Langsa Lama Kota Langsa ditinjau dari aspek finansial dan aspek teknis?

\section{Tujuan Penelitian}

Adapun tujuan dari penelitian ini adalah untuk mengetahui kelayakan usahatani karet rakyat di Kecamatan Langsa Lama Kota Langsa ditinjau dari aspek finansial dan aspek teknis.

\section{Lokasi dan Waktu Penelitian}

\section{METODE PENELITIAN}

Penelitian ini dilakukan di Kecamatan Langsa Lama, Kota Langsa.Penentuan lokasi ini ditentukan secara purposive dengan pertimbangan bahwa di daerah tersebut merupakan salah satu daerah penghasil tanaman karet dengan luas areal lahan karet yang memadai dimana sebagian masyarakatnya berprofesi sebagai petani karet.Penelitian dilakukan pada bulan Februari.

\section{Objek dan Ruang Lingkup Penelitian}


Objek dari penelitian ini terfokus kepada usahatani karet.Ruang lingkup dari penelitian ini dibatasi pada kelayakan usahatani karet milik rakyat atau perseorangan di Kecamatan Langsa Lama Kota Langsa yang ditinjau dari aspek finansial dan aspek teknis.

\section{Sumber dan Metode Pengumpulan Data}

Data yang digunakan dalam penelitian ini adalah data primer dan data sekunder.Data primer adalah data yang diperoleh melalui wawancara dengan para petani karet secara langsung, sedangkan data sekunder diperoleh dari Badan Pusat Statistik (BPS), instansi terkait dan studi kepustakaan.Data tersebut nantinya digunakan dalam pengujian dan analisa dalam penelitian ini.

\section{Analisis Kelayakan Finansial}

Model analisis yang digunakan untuk hipotesis ini adalah analisis deskriptif dan kuantitatif.Data deskriptif dilakukan untuk memperoleh gambaran aspek teknis dan aspek pasar.Data deskriptif aspek teknis dengan melihat lokasi usahatani, teknologi dan alat yang digunakan dan juga keadaan lingkungan sekitar usahatani tersebut. Analisis aspek finansial dengan menggunakan kriteria-kriteria sebagai berikut : Net Present Value (NPV), Net Benefit Cost Ratio (Net B/C), Internal Rate of Return (IRR), Payback Period (PP) dan Analisis Sensitivitas.

\section{Net Present Value (NPV)}

Menurut Husnan (2000), metode net present value ini menghitung selisih antara nilai sekarang investasi dengan penerimaan-penerimaan kas bersih (operasional maupun terminal cash flow) dimasa yang akan datang.

$$
\mathrm{NPV}=\sum_{t=0}^{n} \frac{\left(B_{t}-C_{t}\right)}{(1+i)^{n}}
$$

\section{Keterangan:}

$\mathrm{Bt}=$ Penerimaan (benefit) finansial dari usahatani karet pada tahun $\mathrm{t}$

$\mathrm{Ct}=$ Biaya finansial usahatani pada tahun $\mathrm{t}, \mathrm{Ct}$ dihitung per hektar per tahun

$\mathrm{i}=$ Discount Rate

$\mathrm{n}=$ Umur ekonomis proyek dalam perhitungan dipergunakan setiap 1 tahun pemeliharaan (Soekartawi, 1991).

Kriteria yang dipakai adalah:

Bila nilai NPV > 0 maka usahatani dikatakan layak

Bila nilai NPV $=0$ maka usahatani berada pada posisi break event point

Bila nilai NPV $<0$ maka usahatani dikatakan tidak layak

\section{Net Benefit and Cost Ratio (BC Ratio)}

$$
\text { Net B/C }=\frac{\sum_{t=0}^{n} \frac{\left(B_{t}-C_{t}\right)}{(1+i)^{n}}}{\sum_{t=0}^{n} \frac{\left(C_{t}-B_{t}\right)}{(1+i)^{n}}}
$$




\section{Keterangan:}

$\mathrm{Bt}=$ Penerimaan yang diperoleh pada tahun ke-t

$\mathrm{Ct}=$ Biaya yang dikeluarkan pada tahun ke- $\mathrm{t}$

$\mathrm{i}=$ Tingkat suku bunga $(\%)$

$\mathrm{t}=$ Umur proyek (tahun)

$\mathrm{n}=$ Jumlah tahun

Kriteria kelayakan investasi berdasarkan nilai Net B/C adalah, jika diperoleh nilai Net $\mathrm{B} / \mathrm{C}<1$ menunjukkan bahwa manfaat yang akan diperoleh dari suatu usaha lebih kecil dibandingkan dengan biaya yang dikeluarkan maka proyek tidak layak untuk dilaksanakan, tetapi jika nilai Net B/C $=1$ atau Net B/C > 1, maka proyek tersebut layak untuk dijalankan (Afnita, 2002).

\section{Internal Rate of Return (IRR)}

Menurut Husnan \& Suwarsono (2000), metode Internal Rate of Return (IRR) adalah menghitung tingkat bunga yang menyamakan nilai sekarang investasi dengan nilai sekarang penerimaan-penerimaan kas bersih di masa-masa mendatang. Apabila tingkat bunga ini lebih besar dari pada tingkat bunga relevan (tingkat keuntungan yang disyaratkan), maka investasi dikatakan menguntungkan, kalau lebih kecil dikatakan merugikan.Dalam Husnan \& Suwarsono, (2000). Rumus dari IRR sebagai berikut:

$$
\mathrm{IRR}=i_{1}+\frac{N P V_{1}}{N P V_{1}-N P V_{2}}\left(i_{2}-i_{1}\right)
$$

Keterangan :

i1 $=$ Discount Rate ke -1

i2 = Discount Rate ke -2

NPV1= Nilai net present value -1

NPV2 $=$ Nilai net present value -2

Kriteria yang dipakai adalah:

Bila IRR > tingkat suku bunga berlaku maka usahatani layak untuk dilaksanakan.

Bila IRR < tingkat suku bunga berlaku maka usahatani tidak layak untuk dilaksanakan (Kadariah, 2009).

\section{Payback Period (PP)}

Payback Period merupakan metode yang digunakan untuk menghitung lama periode yang di perlukan untuk mengembalikan uang yang telah diinvestasikan dari aliran kas masuk tahunan yang dihasilkan oleh usahatani tersebut.

Rumus periode pengembalian (payback period)jika arus kas per tahun jumlahnya berbeda, yaitu: 


$$
\text { Payback Period }=\mathrm{n}+\frac{(a-b)}{(c-b)} \times 1 \text { tahun }
$$

Keterangan:

$\mathrm{n}=$ tahun terakhir dimana jumlah arus kas masih belum bisa menutup investasi awal

$\mathrm{a}=$ jumlah investasi mula-mula

$\mathrm{b}=$ jumlah kumulatif arus kas pada tahun ke-n

$\mathrm{c} \quad=$ jumlah kumulatif arus kas pada tahun ke $\mathrm{n}+1$

Kriteria yang dipakai:

Usahatani dinyatakan layak jika payback period lebih pendek dibandingkan periode payback maksimum.

Usahatani dinyatakan tidak layak apabila payback period lebih panjang daripada periode payback maksimum.

\section{Analisis Sensitivitas}

Analisis sensitivitas atau uji kepekaan untuk melihat apakah yang akan terjadi dengan hasil nilai analisa proyek (manfaat atau biaya) karena dapat suatu kesalahan atau perubahan dalam dasar-dasar perhitungan (kenaikan harga faktor produksi atau penurunan harga jual produksi). Pada analisis kepekaan setiap kemungkinan harus diuji, yang berarti bahwa setiap perubahan harus dianalisis kembali.Hal ini dilakukan karena umumnya analisis suatu proyek didasarkan atas proyeksi-proyeksi yang banyak mengandung ketidakpastian. Perubahan dapat saja terjadi terhadap harga dan produksi, sehingga akan menyebabkan perubahan biaya dan penerimaan proyek.

\section{Analisis Kelayakan Usahatani}

\section{HASIL DAN PEMBAHASAN}

Analisis biaya dan manfaat merupakan bahan pertimbangan dalam mengambil suatu keputusan, apakah layak atau tidak layak suatu usaha yang dijalankan. Apabila suatu usaha layak dijalankaan, maka usaha yang dijalankan tersebut akan mampu memberi manfaat (benefit) bagi pengusaha (Ibrahim, 2008). Dalam penelitian ini kriteria investasi yang digunakan dalam penilaian apakah usahatani karet di Kecamatan Langsa Lama Kota Langsa layak untuk diusahakan adalah Net Present Value (NPV), Net Benefit Cost Ratio (Net B/C), dan Internal Rate of Return (IRR).

Usahatani karet rakyat di Kecamatan Langsa Lama Kota Langsa layak diusahakan apabila $\mathrm{NPV}>0$, Net B/C > 1 dan IRR > tingkat suku bunga yang berlaku pada umur ekonomis proyek. Adapun hasil analisis kelayakan usahatani karet rakyat di Kecamatan Langsa Lama Kota Langsa adalah sebagai berikut:

a) Net Present Value pada DF 18\% adalah sebesar Rp. 24.128.831

b) Net Benefit Cost Ratio (Net B/C) adalah sebesar 2,49

c) Internal Rate of Return (IRR) adalah sebesar $\mathbf{4 0 , 4 2 \%}$

Berdasarkan hasil analisis di atas, maka usahatani karet rakyat di Kecamatan Langsa Lama Kota Langsa layak untuk diusahakan.Hal ini disebabkan nilai NPV > 0, yaitu sebesar Rp. 24.128.831 yang berarti penerimaan yang diperoleh lebih besar dari biaya yang dikeluarkan. Net B/C > 1 yaitu sebesar 2,49 dan IRR sebesar 40,42\% menunjukkan

Analisis Kelayakan Usahatani Karet Rakyat Di Kecamatan Langsa Lama Kota Langsa 337 (Daris Hudaya, Mustafa Usman, T.Makmur,)

Jurnal Ilmiah Mahasiswa Pertanian Unsyiah, Vol.3, No.4, November 2018:333-341 
bahwa tingkat pengembalian modal usahatani karet rakyat lebih besar dari tingkat suku bunga $18 \%$.

d) Payback Period (PP)

Payback Period merupakan metode yang digunakan untuk menghitung lama periode yang di perlukan untuk mengembalikan uang yang telah diinvestasikan dari aliran kas masuk tahunan yang dihasilkan oleh usahatani tersebut.Dari hasil tabel 4.3 di atas dapat dilihat besarnya biaya investasi yang dikeluarkan pada usahatani karet rakyat di Kecamatan Langsa Lama Kota Langsa pada tahun ke-0 sampai dengan tahun ke-5 adalah sebesar Rp. 8.033.500 dengan rincian biaya investasi meliputi biaya tenaga kerja, biaya sarana produksi dan biaya peralatan. Dan selanjutnya pada tahun ke-6 usahatani baru memiliki pendapatan hasil produksi dari hasil penjualan produksi karet sehingga pendapatan usahatani dapat dilihat pada tabel 4.7.Dengan demikian dapat disimpulkan bahwa waktu atau periode pengembalian usaha tani karet rakyat di Kecamatan Langsa Lama Kota Langsa adalah 5 tahun.

\section{e) Analisis Sensitivitas}

Analisis sensitivitas bertujuan untuk melihat kemungkinan-kemungkinan yang terjadi dengan hasil analisis suatu usahatani apabila terdapat suatu kesalahan atau suatu perubahan dalam dasar-dasar perhitungan biaya dan manfaat. Dalam analisis ini setiap kemungkinan harus diuji, karena analisis usahatani didasarkan pada proyeksi di masa akan datang (Gittinger, 2006).

Dalam penelitian ini, analisis sensitivitas didasarkan pada adanya perubahan kemungkinan dalam tingkat harga, baik harga barang-barang produksi maupun harga jual karet. Beberapa kemungkinan-kemungkinan yang akan dianalisis dalam analisis ini adalah:

1) Asumsi biaya produksi naik sebesar $10 \%$ sedangkan penerimaan tetap.

2) Asumsi biaya produksi tetap sedangkan penerimaan turun $10 \%$.

Dalam kemungkinan-kemungkinan tersebut maka diperoleh hasil analisis sebagai berikut.

1) Kemungkinan Pertama

a) Net Present Value pada DF 18\% adalah sebesar Rp. 22.513.553

b) Net Benefit Cost Ratio (Net B/C) adalah sebesar 2,27

c) Internal Rate of Return (IRR) adalah sebesar 40,42\%

2) Kemungkinan Kedua

a) Net Present Value pada DF 18\% adalah sebesar Rp. 20.100.670

b) Net Benefit Cost Ratio (Net B/C) adalah sebesar 2,24

c) Internal Rate of Return (IRR) adalah sebesar 37,94\%

Dari hasil analisis di atas dapat dilihat bahwa nilai NPV $>0$, Net B/C $>1$ dan IRR lebih besar dari suku bunga yang berlaku.Dengan demikian dapat ditarik kesimpulan bahwa hipotesis dapat diterima.Dalam artian bahwa usahatani karet rakyat di Kecamatan Langsa Lama Kota Langsa layak untuk dilanjutkan dan dikembangkan baik dari aspek finansial dan aspek teknis.

\section{f) Tinjauan Aspek Sosial}

Produksi karet dapat ditingkatkan salah satunya dengan memperhatikan kesesuaian suatu lahan terhadap tanaman karet dapat menjadi maksimal karena hal ini dapat kita ketahui

Analisis Kelayakan Usahatani Karet Rakyat Di Kecamatan Langsa Lama Kota Langsa 338 (Daris Hudaya, Mustafa Usman, T.Makmur,)

Jurnal Ilmiah Mahasiswa Pertanian Unsyiah, Vol.3, No.4, November 2018:333-341 
dengan melakukan evaluasi lahan. Evaluasi lahan merupakan proses pendugaan potensi lahan untuk bermacam alternatif penggunaan lahan, ini merupakan cara yang biasa digunakan dalam perencanaan penggunaan lahan.

Suatu survey evaluasi tanah baru memiliki kegunaan yang dilaksanakan dengan teliti dalam pengambilan sampel, deskripsi, analisis data, dan interpretasi yang digunakan sudah tepat atau benar. Kesesuaian lahan perlu diperhatikan untuk tanaman budidaya agar mendapatkan pertumbuhan yang optimal, walau tanaman kelihatan dapat tumbuh bersama disatu wilayah, akan tetapi setiap jenis tanaman mempunyai karakter yang membutuhkan persyaratan yang berbeda-beda. Dengan demikian supaya produksi dapat optimal maka harus diperhatikan antara kesesuaian lahan untuk tanaman pertanian dan persyaratan tumbuh tiap jenis tanamannya.

Usaha perluasan ibukota dalam hal ini Kota Langsa sedikit banyak telah menghambat perluasan lahan usahatani karet di sekitar wilayah Kota Langsa terutama Kecamatan Langsa Lama dan merupakan salah satu kecamatan yang terdekat dengan ibukota Kabupaten/Kota. Upaya perluasan tersebut, dari sisi tata ruang dan wilayah akan memberi ruang perencanaan wilayah yang lebih luas bagi pemerintah, terutama dalam rangka menciptakan pusat-pusat pertumbuhan ekonomi baru yang meliputi di dalamnya pusat pasar.

Selain itu, berkurangnya lahan perkebunan karet rakyat juga disebabkan oleh alih fungsi lahan.Instansi terkait dalam hal ini Dinas Pertanian dan Perkebunan menyebutkan bahwa seluas sekitar 10.000 Ha lahan perkebunan karet rakyat di wilayah Kota Langsa telah beralih fungsi menjadi kebuh kelapa sawit selama beberapa tahun terakhir.Salah satunya mencakup lahan perkebunan karet yang ada di Kecamatan Langsa Lama Kota Langsa. Petani secara mandiri mengalihfungsikan lahan perkebunan karet menjadi sawit dan mengubah komoditi perkebunannya karena faktor ekonomi.Hal ini dikarenakan petani menganggap sawit lebih menguntungkan dibandingkan karet dalam aspek stabilitas penetapan harga.

\section{SIMPULAN DAN SARAN}

\section{Simpulan}

Berdasarkan hasil penelitian yang telah dilakukan dapat disimpulkan beberapa hal sebagai berikut:

1) Usahatani karet rakyat di Kecamatan Langsa Lama Kota Langsa layak untuk diusahakan bila ditinjau dari aspek finansial. Hal ini dapat dilihat dari nilai NPV > 0, yaitu sebesar Rp. 24.128.831 yang berarti penerimaan yang diperoleh lebih besar dari biaya yang dikeluarkan. Net B/C > 1 yaitu sebesar 2,49 dan IRR sebesar $40,42 \%$ menunjukkan bahwa tingkat pengembalian modal usahatani karet rakyat lebih besar dari tingkat suku bunga $18 \%$.

2) Dari aspek teknis dapat dijelaskan bahwa para petani karet rakyat di Kecamatan Langsa Lama Kota Langsa cenderung sudah cukup baik, hal ini dapat dilihat dari prosedur pengolahan, lokasi lahan yang sangat mendukung, pemilihan bibit unggul dan penggunaan tenaga kerja yang tepat.

Analisis Kelayakan Usahatani Karet Rakyat Di Kecamatan Langsa Lama Kota Langsa 339 (Daris Hudaya, Mustafa Usman, T.Makmur,)

Jurnal Ilmiah Mahasiswa Pertanian Unsyiah, Vol.3, No.4, November 2018:333-341 


\section{Saran}

Beberapa saran yang dapat diharapkan dari hasil penelitian ini antara lain:

1) Diharapkan kepada pemerintah agar dapat mengarahkan lokasi yang memadai bagi petani karet untuk membantu mereka dalam mengembangkan produksi karet dan perluasan lahan milik masyarakat.

2) Diharapkan kepada petani karet rakyat agar dapat lebih mengembangkan usahataninya secara intensif sehingga dapat meningkatkan produksinya dan juga mempertimbangkan aspek penggunaan lahan yang maksimal.

3) Disarankan kepada lembaga atau institusi terkait agat dapat lebih memberikan perhatian dalam penyuluhan terkait aspek-aspek penting dalam mengembangkan usahatani serta berperan dalam penyediaan pupuk dan bibit yang baik.

\section{DAFTAR PUSTAKA}

Afnita. 2002. Analisis Kelayakan Investasi Paprika dengan Sistem Pertanian Organik di PT Austindo Mitra Sarana Farm.

Anwar, Chairil. 2006. Perkembangan Pasar dan Prospek Agribisnis Karet diIndonesia. Medan.

Arikunto, Suharsimi. 2006. Metode Penelitian: Suatu Pendekatan Praktik. Jakarta: Rineka Cipta.

Badan Pusat Statistik (BPS). 2013. Aceh Dalam Angka. Provinsi Aceh.

Cholik, 2003.Teori Mikro Ekonomi. Yogyakarta: Percetakan Andi Offset.

Direktorat Jenderal Bina Produksi Perkebunan.2010. Statistik Perkebunan Indonesia Komoditas Karet. Jakarta.

Gilarso. 2007. Pengantar Ilmu Ekonomi Makro. Edisi Pertama. IKAPI.Yogyakarta.

Gittinger, J.P. 2006. Analisa Ekonomi Proyek-Proyek Pertanian. Terjemahan. Edisi Kedua. UI-Press \&John Hopkins. Jakarta.

Hernanto, F. 2001. Petani Kecil, Potensi dan Tantangn Pembangunan. Jakarta: Ganesha.

Husnan, Suad \&Suwarsono Muhammad. 2000. Studi Kelayakan Proyek. Edisi Keempat, Penerbit UPP AMP YKPN, Yogyakarta.

Ibrahim, M.Y. 2008. Studi KElayakan Bisnis. Jakarta: Rineka Cipta.

Kadariyah, dkk. 2009. Pengantar Evaluasi Proyek. Jakarta: Fakultas Ekonomi Universitas Indonesia.

Analisis Kelayakan Usahatani Karet Rakyat Di Kecamatan Langsa Lama Kota Langsa 
Kasmir \& Jakfar. 2003. Studi Kelayakan Bisnis. Jakarta: Kencana Prenada Group.

Mardikanto, Totok. 2003. Sistem Penyuluhan Pertanian. Surakarta: Universitas Sebelas Maret.

Pane, A. A. 2014.Sistem Bagi Hasil dan Pendapatan Petani Padi di Kabupaten Seluma Provinsi Bengkulu. Bengkulu: Universitas Bengkulu.

Pane, AA. 2011. Prospektif Harga Karet. Jakarta: Peragi.

Priyanto, Ichwan. 2013. Efektivitas Pemupukan Tanaman Karet. Jakarta: Gramedia.

Siregar, Tumpal.H.S, dkk. 2010. Budidaya Pengolahan Cokelat. Jakarta: Penebar Swadaya.

Soekartiwi. 2013. Teori Ekonomi Produksi. Jakarta: Rajawali.

Sugiyono. 2008. Metode Penelitian Kuantitatif Kualitatif dan R\&D. Bandung: Alfabeta.

Sukirno, Sadono. 2008. Teori Pengantar Ekonomi Makro.Edisi ke Tiga.Jakarta: PT. Raja Grafindo Persada.

Suratiyah, K. 2011. Ilmu Usahatani. Bogor: Penebar Swadaya

Suratman. 2002. Studi Kelayakan Proyek. Malang: Proyek Peningkatan Penelitian Pendidikan Tinggi, Direktorat Jenderal Pendidikan Tinggi, Departemen Pendidikan Nasional.

Suryabrata, Sumadi. 2011. Psikologi Pendidikan. Jakarta: PT. Raja Grafindo Persada

Suwarto. 2010. Budidaya Tanaman Unggulan Perkebunan. Jakarta: Penebar Swadaya.

Tim Penulis. 2008. Panduan Lengkap Karet. Jakarta: Penebar Swadaya.

Umar, Husein. 2007. Studi Kelayakan Bisnis. Edisi Ketiga. Jakarta: PT. Gramedia Pustaka Utama. 